he received several blood transfusions which may have provided sufficient lymphocytes to mount an attack against the warts. The marked depletion of peripheral lymphocytes in this patient was in contrast to the maintenance of normal serum proteins, including immunoglobulins. This is of interest in view of the close similarity of hyperplastic lymphoid follicles (Fig. 6) with the nodular lymphoid hyperplasia found in hypogammaglobulinaemia (Hermans et al., 1966) and which is known to be associated with infection with Giardia lamblia.

Despite the marked depression of immune function in patients with lymphangiectasia opportunistic infections do not appear to be unduly common (Strober et al., 1967) and the authors have been unable to find any other reports of malignancy complicating this condition. It is perhaps the severity of their patient's lymphocyte depletion which has accounted for the appearance of such gross viral warts and ultimately to the complication of small intestinal lymphoma.

\section{References}

BURNET, F.M. (1957) Cancer-a biological approach. British Medical Journal, 1, 779.

GATTI, R.A. \& GooD, R.A. (1971) Occurrence of malignancy in immunodeficiency diseases. Cancer, $28,89$.

Hermans, P.E., Huizenga, K.A., Hoffman, H.N., Brown,
A.L. \& MarkowITz, H. (1966) Dysgammaglobulinaemia associated with nodular lymphoid hyperplasia of the small intestine. American Journal of Medicine, 40, 78.

Leibowitz, S. \& Schwartz, S. (1971) Malignancy as a complication of immunosuppressive therapy. In: Advances in Internal Medicine (Ed. by G. H. Stollerman). Year Book Medical Publishers, 17,

Penn, I., Hammond, W., Brettschneider, L. \& Starzl, T.E. (1969) Malignancy lymphoma in transplantation patients. Transplantation Proceedings, 1 (1), 106.

Roberts, S. \& Douglas, A.P. (1976) Intestinal lymphangiectasia: A study of five cases. Quarterly Journal of Medicine, $177,39$.

Ross, J.D., Reid, K.D.G., Ambujakshank, V.P., KInloch, J.P. \& SIRCUS, W. (1971) Recurrent pleural effusion, protein-losing enteropathy, malabsorption and mosaic warts associated with generalized lymphatic hyperplasia. Thorax, 76, 119.

SChNeCK, S.A. \& PenN, I. (1971) 'De Novo' brain tumour in renal transplant patient. Lancet, i, 983.

Strober, W., Wochner, R.D., Carbone, P.P. \& Waldmann, T.A. (1967) Intestinal lymphangiectasia: a protein-losing enteropathy with hypogammaglobulinaemia, lymphocytopenia and impaired homograft rejections. Journal of Clinical Investigation, 46, 1643.

Ten Besel, R.W., Studlan, E.M. \& Krivit, W. (1966) The development of malignancy in the course of the Aldrich syndrome. Journal of Pediatrics, 68, 769.

ThомAs, L. (1959) Reaction to homologous tissue antigens in relation to hypersensitivity. In: Cellular and Humoral Aspects of the Hypersensitive State (Ed. by H. S. Laurence), p. 529. Paul B. Hoeber, New York.

WhiteheAD, R. (1973) In: Mucosal Biopsy of the Gastrointestinal Tract, p. 116. W. B. Saunders Co. Ltd.

\title{
Quadriceps myositis: an appraisal of the diagnostic criteria of quadriceps myopathy
}

\author{
P. D. MOHR \\ B.Sc., M.B., Ch.B., M.R.C.P. \\ T. G. KNOWLSON \\ M.B., Ch.B., M.R.C.Path. \\ Departments of Neurology and Neuropathology, University of Manchester, Manchester
}

\begin{abstract}
Summary
A patient with the clinical picture of quadriceps myopathy was shown to have an underlying myositis. Review of the literature showed myositis to be a rare cause of the 'quadriceps syndrome' but it is important to identify this group because they are potentially treatable with corticosteroids.

\section{Introduction}

Selective wasting and weakness of the quadriceps muscles has been reported in two patients with
\end{abstract}

myositis (Denny-Brown, 1939; Turner and Heathfield, 1961), two patients with unspecified myopathy (Bramwell, 1922), twelve patients with muscular dystrophy (Erb, 1891; Walton, 1956; Mümenthaler et al., 1958; Wijngaarden et al., 1968; Espir and Matthews, 1973) and one patient with chronic spinal muscular atrophy (Boddie and Stewart-Wynne, 1974). The latter report suggested that quadriceps myopathy is a clinical syndrome with various underlying pathologies. A further patient with quadriceps wasting due to a myositis is now reported and the 
diagnostic criteria for inclusion in the 'quadriceps syndrome' are discussed.

\section{Case report}

A 38-year-old man was referred to the neurology clinic in 1974. He had first noticed difficulty in walking, climbing ladders and rising from a squatting position in 1970. These symptoms persisted for one year and then improved after a course of physiotherapy. In 1973 the symptoms returned in a more severe form and he now noticed a tendency for his knees to give way, and rapid wasting of his thigh muscles. He had no other neurological symptoms and there was no family history of any neuromuscular disorder. On examination he had striking wasting and weakness of his quadriceps muscles (Fig. 1). The wasting was more marked proximally and additional weakness was noted in extension, flexion and abduction of the hips. Power and bulk in other muscles, the deep tendon reflexes and sensation were all normal.

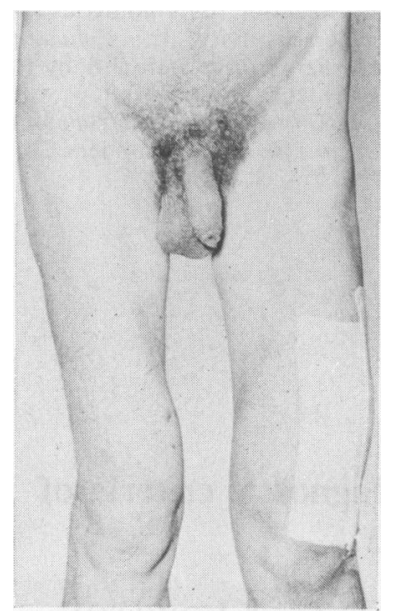

FIG. 1. Patient with marked wasting of the quadriceps muscles.

Laboratory investigations showed a marked elevation of the serum creatinine phosphokinase (1750 i.u./l) and serum aldolase (18 i.u./l) and a slight increase of the serum globulin $(38 \mathrm{~g} / \mathrm{l})$ with an elevated gamma fraction on electrophoresis. A large number of other investigations were normal including a full blood count, erythrocyte sedimentation rate, blood urea and electrolytes, serum calcium, glucose tolerance test, thyroid function tests, screening for rheumatoid factor and antinuclear factor, chest X-ray and electrocardiogram.

Concentric needle electromyography (EMG) was performed on the right deltoid, triceps, biceps, ileopsoas, rectus femoris, and first dorsal interosseous muscles. In the deltoid and triceps muscles scanty spontaneous fibrillations were present. The interference pattern was complete but of reduced amplitude, $0.5-1.0 \mathrm{mV}$. Occasional positive sharp waves were also seen in the triceps muscle. The biceps and first dorsal interosseous muscles showed no spontaneous activity and a complete interference pattern of $1.5-2 \mathrm{mV}$. In the rectus femoris and ileopsoas muscles spontaneous fibrillation and positive sharp waves were noted. The interference pattern was complete with an amplitude of 1.0-1.5 mV. There were copious short duration polyphasic units. No fasciculation was seen. Maximum motor conduction velocities of median and lateral popliteal nerves were normal. It was concluded that there were widespread myopathic changes combined with evidence of degeneration and this pattern was considered compatible with myositis.

A muscle biopsy was taken from the left rectus femoris muscle (Figs 2 and 3 ) and examined in longitudinal and transverse section. Large numbers of muscle fibres were abnormal showing variation in size and shape. Some showed marked eosinophilia and fragmentation and the more degenerate fibres

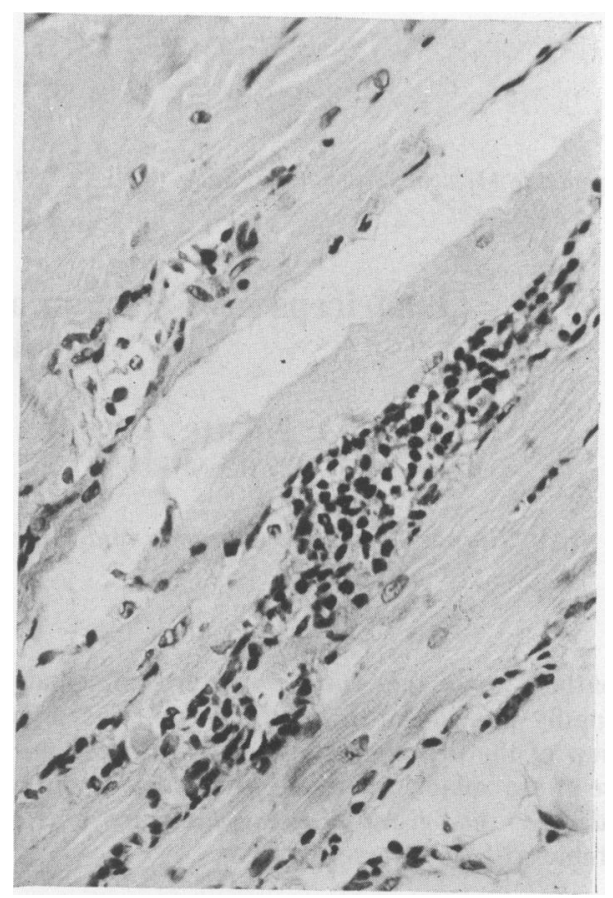

FIG. 2. Longitudinal section showing focal collections of non-specific chronic inflammation cells between the muscle bundles and some fatty replacement. (HE, $\times 350$.) 


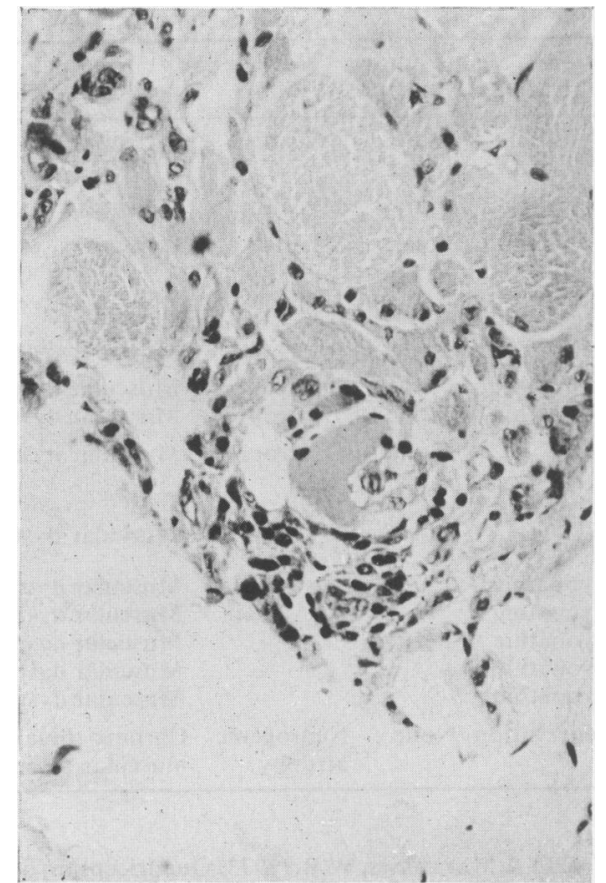

FIG. 3. Transverse section showing variation in muscle fibre size, degenerate muscle fibres with macrophage removal and round cell infiltration. (HE, original magnification $\times 350$.)

were being removed by macrophage activity. Central nuclei were present in many fibres and fatty replacement had occurred. Large numbers of lymphocytes and plasma cells were seen between the muscle bundles and even surrounding individual fibres. The nerve twigs and motor end plates were normal and there was no evidence of vasculitis either recent or healed. The appearances were those of active chronic inflammation but no aetiological agent was revealed by differential staining.

The investigations suggested that this patient's 'quadriceps syndrome' was due to a myositis and he was treated with prednisolone $60 \mathrm{mg}$ daily. After 6 months the patient's muscle power had returned to normal and the bulk of his thighs increased by 2.5 $\mathrm{cm}$ in circumference. The serum creatinine phosphokinase fell to $80 \mathrm{i}$.u./l, the serum aldolase to 3.9 i.u./l and the serum globulin to $30 \mathrm{~g} / \mathrm{l}$ with normal electrophoresis. The prednisolone was gradually reduced to its present level of $10 \mathrm{mg}$ daily, the muscle power and bulk have remained unchanged even though the serum creatinine phosphokinase rose to 314 i.u./l.

\section{Discussion}

The term quadriceps myopathy is not a strict anatomical definition because, as in the present case, many of the previous reports indicate that patients may have lesser degrees of weakness in other muscles of the pelvic girdle or even in the upper limbs (Denny-Brown, 1939; Bramwell, 1922; Espir and Matthews, 1973), while in some other patients the upper limbs may be clinically normal but show myopathic changes on electromyography (Mümenthaler et al., 1958; Wijngaarden et al., 1968).

A review of the previous reports (Table 1) indicates that the 'quadriceps syndrome' may be due to forms of myositis, muscular dystrophy or spinal muscular atrophy but the final classification of each patient has always proved difficult; firstly, because the late onset and menopausal forms of so-called muscular dystrophy are probably examples of polymyositis and sometimes respond to steroids (Adams, Denny-Brown and Pearson, 1953; Bates, Stevens and Hudgson, 1973). Secondly, because some patients once considered to have muscular dystrophy have later been shown to have benign spinal muscular atrophy (Emery, 1971). Thirdly, inflammatory reactions may occur in the muscle biopsies of patients with muscular dystrophy (Munsat et al., 1972) and fourthly, because it has been suggested that neurogenic factors may play a role in some forms of muscular dystrophy (McComas, Sica and Campbell, 1971).

Despite these difficulties it is important in clinical practice to recognize patients with a quadriceps myositis because of the benefits of treatment with corticosteroids as demonstrated in the present case. Therefore, the authors have tried to identify common features in the previous case reports which may indicate the underlying pathology. However, the age of onset, duration of the illness, absent knee jerks, and muscle enzyme levels did not show any correlation with the final classification. The patients considered to have myositis did not show any features such as a raised erythrocyte sedimentation rate, skin rash, evidence of an underlying collagenvascular disorder or muscle pains; indeed, the latter was noted as a feature in one family with muscular dystrophy (Espir and Matthews, 1973). A positive family history was noted in two reports and this favours muscular dystrophy. Electromyographic changes may be minimal (Turner and Heathfield, 1961) and a muscle biopsy is required for the final classification. The clinical picture of the present patient was identical to those patients reported with muscular dystrophy but the muscle biopsy showed evidence of severe inflammation and he had a gratifying response to corticosteroids.

The 'quadriceps syndrome', like other neuromuscular syndromes, has proved to be a clinical entity which has different pathological causes and always requires full clinical, laboratory and pathological evaluation for diagnosis. 
TABLE 1. Previous cases of quadriceps myopathy

\begin{tabular}{|c|c|c|c|c|c|c|c|c|}
\hline Author(s) & $\begin{array}{c}\text { Age/Sex } \\
\text { (years) }\end{array}$ & $\begin{array}{l}\text { Knee } \\
\text { jerks }\end{array}$ & Upper limbs & $\begin{array}{c}\text { Muscle } \\
\text { enzymes }\end{array}$ & EMG & $\begin{array}{l}\text { Family } \\
\text { history }\end{array}$ & $\begin{array}{l}\text { Muscle } \\
\text { biopsy }\end{array}$ & $\begin{array}{c}\text { Final } \\
\text { classification }\end{array}$ \\
\hline Denny-Brown 1939 & $43 \mathrm{~F}$ & Absent & Slight wasting & & Myositis & None & Myositis & Myositis \\
\hline $\begin{array}{l}\text { Turner \& Heathfield } \\
\text { (1961) }\end{array}$ & $52 \mathrm{~F}$ & Absent & & & Myositis & None & Myositis & Myositis \\
\hline Present case (1977) & $38 \mathrm{M} \mathrm{I}$ & Normal & EMGs abnormal & $\uparrow$ & Myositis & None & Myositis & Myositis \\
\hline Bramwell (1922) & $\begin{array}{l}53 \mathrm{~F} \\
59 \mathrm{M}\end{array}$ & $\begin{array}{l}\text { Absent } \\
\text { Absent }\end{array}$ & Absent pectorals & & & & - & ? Myopathy \\
\hline Erb (1891) & $59 \mathrm{M}$ & Absent & & & & & - & Muscular dystrophy \\
\hline Walton (1956) & $\begin{array}{l}22 \mathrm{M} \\
57 \mathrm{M}\end{array}$ & $\begin{array}{l}\text { Normal } \\
\text { Reduced }\end{array}$ & & & $\begin{array}{l}\text { Myopathic } \\
\text { Myopathic }\end{array}$ & $\begin{array}{l}\text { None } \\
\text { None }\end{array}$ & $\begin{array}{l}\text { Dystrophic } \\
\text { Dystrophic }\end{array}$ & $\begin{array}{l}\text { Muscular dystrophy } \\
\text { Muscular dystrophy }\end{array}$ \\
\hline $\begin{array}{l}\text { Mümenthaler } \\
\text { et al. (1958) }\end{array}$ & $\begin{array}{l}53 \mathrm{M} \\
43 \mathrm{M}\end{array}$ & $\begin{array}{l}\text { Reduced } \\
\text { Reduced }\end{array}$ & EMGs abnormal & & & None & Dystrophic & Muscular dystrophy \\
\hline $\begin{array}{l}\text { Van Wijngaarden } \\
\text { et al. (1968) }\end{array}$ & $\begin{array}{l}38 \mathrm{M} \\
34 \mathrm{M}\end{array}$ & $\begin{array}{l}\text { Normal } \\
\text { Reduced }\end{array}$ & $\begin{array}{l}\text { EMGs abnormal } \\
\text { EMGs abnormal }\end{array}$ & $\begin{array}{l}\uparrow \\
\uparrow\end{array}$ & $\left.\begin{array}{l}\text { Myopathic } \\
\text { Myopathic }\end{array}\right\}$ & Positive & Dystrophic & Muscular dystrophy \\
\hline $\begin{array}{l}\text { Espir \& Matthews } \\
\text { (1973) }\end{array}$ & $\begin{array}{l}53 \mathrm{M} \\
61 \mathrm{M} \\
31 \mathrm{~F} \\
29 \mathrm{~F} \\
25 \mathrm{~F}\end{array}$ & $\begin{array}{l}\text { Absent } \\
\text { Absent } \\
\text { Normal } \\
\text { Normal } \\
\text { Normal }\end{array}$ & $\begin{array}{l}\text { Slight wasting } \\
\text { Slight wasting }\end{array}$ & $\begin{array}{c}\uparrow \\
\uparrow \\
\text { Normal }\end{array}$ & $\left.\begin{array}{l}\text { Myopathic } \\
\text { Myopathic } \\
\text { Myopathic } \\
\text { Myopathic } \\
\text { Myopathic }\end{array}\right\}$ & Positive & $\begin{array}{c}\text { Distrophic } \\
- \\
- \\
-\end{array}$ & $\begin{array}{l}\text { Muscular dystrophy } \\
\text { Muscular dystrophy } \\
\text { Muscular dystrophy } \\
\text { Muscular dystrophy } \\
\text { Muscular dystrophy }\end{array}$ \\
\hline $\begin{array}{l}\text { Boddie \& Stewart- } \\
\text { Wynne (1974) }\end{array}$ & $44 \mathrm{M}$ & Absent & & $\uparrow$ & Denervation & None & $\begin{array}{l}\text { Neurogenic } \\
\text { atrophy }\end{array}$ & $\begin{array}{l}\text { Chronic spinal } \\
\text { muscular atrophy }\end{array}$ \\
\hline
\end{tabular}

\section{Acknowledgments}

We would like to thank Dr L. A. Liversedge and Professor P. Yates for permission to report this case and their help in preparing this paper.

\section{References}

Adams, R.D., Denny-Brown, D. \& Pearson, C.M. (1953) Diseases of Muscle. P. B. Hoeber Inc., New York.

Bates, D., Stevens, J.C. \& Hudgson, P. (1973) Polymyositis with involvement of facial and distal musculature: one form of the facioscapulohumeral syndrome. Journal of the Neurological Sciences, 10, 105.

Boddie, H.G. \& STEWART-WynNe, E.G. (1974) Quadriceps myopathy-entity or syndrome. Archives of Neurology, 31, 60.

Bramwell, E. (1922) Observations on myopathy. Proccedings of the Royal Society of Medicine, 16, 1.

DENNY-BROWN, D. (1939) Myopathic weakness of the quadriceps. Proceedings of the Royal Society of Medicine, 32, 867.

EMERY, A.E.H. (1971) The nosology of the spinal muscular atrophies. Journal of Medical Genetics, 8, 481.

ERB, W. (1891) Dystrophia muscularis progessiva: Klinische und pathologisch-anatomische Studien. Deutsche Zeitschrift für Nervenheilkunde, 1, 13.
ESPIR, L.E. \& MATTHEWs, W.B. (1973) Quadriceps myopathy. Journal of Neurology, Neurosurgery and Psychiatry, 36, 1041 .

McComas, A.J.R., SiCA, R.E.P. \& CAMPbell, M.J. (1971) Sick motorneurones: a unifying concept of muscle disease. Lancet, i, 321.

Mümenthaler, M., Bosch, T., Katzenstein, E. \& Lehner, F. (1958) Über den isolierten Befall des M. quadriceps femoris bei der Dystrophia Musculorum progressiva. Confinia Neurologica (Basle), 18, 416.

Munsat, T.L., Piper, D., Cancilla, P. \& Mednick, J. (1972) Inflammatory myopathy with facioscapulohumeral distribution. Neurology (Minneopolis), 22, 335.

Turner, J.W.A. \& Heathfield, K.W.G. (1961) Quadriceps myopathy occurring in middle age. Journal of Neurology, Neurosurgery and Psychiatry, 24, 18.

Van WijngaARden, G.K., Hagen, C.J., Bethlem, J. \& MEIJER, A.E.F. (1968) Myopathy of the quadriceps muscles. Journal of the Neurological Sciences, 7, 201.

Walton, J.N. (1956) Two cases of myopathy limited to the quadriceps. Journal of Neurology, Neurosurgery and Psychiatry, 19, 106. 